\title{
Meadowfoam Seed Oil
}

National Cancer Institute

\section{Source}

National Cancer Institute. Meadowfoam Seed Oil. NCI Thesaurus. Code C72213.

The oil pressed from the seeds of Limnanthes alba. Meadowfoam seed oil is an edible oil with uses in hair and skincare products and industrial applications. 